\title{
nature
}

\section{Bringing enlightenment to the pursuit of justice}

Advances in modern science and medicine have introduced unprecedented dilemmas for both courts and legislators. A rulling in a British case on artificial insemination gives hope that good sense can be made to prevail.

ast week, a British appeals court overruled a decision by the Human Fertilization and Embryo Authority (HFEA) preventing a woman from travelling to Belgium to be inseminated with the sperm of her dead husband. The verdict, directing the HFEA to reconsider its decision, is the latest step in a complex legal battle arising from the fact that the husband had not given his written permission for the insemination. Coincidentally, the verdict was announced on the day that a brief meeting opened in Paris of leading judges and legal experts from around the world, called to debate the rapidly growing interactions between science, medicine and the law.

Until recently, both science and medicine were carried out relatively free of legal constraints (apart from considerations of public safety). One point that became clear at the meeting is that both are increasingly affected by an arsenal of regulations designed, for example, to control the applications of recombinant DNA technology and medically assisted procreation. But there was some disarray among those present about how the law should be applied — if at all - to such complex and fast-moving areas. In particular, doubts were expressed about the legitimacy of using the law to rule on matters that depend partly on the morality of a certain culture and partly on the conscience of individual scientists, physicians and patients.

Some of those present, particularly from France and elsewhere in Europe, argued that the guardians of national constitutions, such as supreme courts and constititional councils, should be recognized as the ultimate arbiters of bioethical issues, particularly given the growing proliferation of situations in which these issues arise. They claim that a reaffirmation of the principles enshrined in a national consti- tution is necessary in such situations to defend fundamental concepts of social justice and individual liberty, including scientific freedom, the non-commercial value of the human body, the need for informed consent to human experiments and - a growing area of concern the protection of 'genetically disadvantaged' individuals.

But others say that constitutional elements may be relevant only in a few areas. Stephen Breyer, for example, a judge of the US Supreme Court, told last week's meeting, 'Constitution and Biomedical Ethics', that many bioethical issues can be adequately dealt with by administrative law, by penal law, or by the decisions of individual ethics committees. Or they can simply be left to market forces. At the same time, Breyer admits that making ideas about the basic rights of human beings explicit in constitutions and international treaties can highlight important considerations and make legislators "stop and think" when introducing new laws.

Last week's case in Britain vividly illustrates the type of dilemma faced by modern courts. The case arose largely because the husband of the woman concerned died unexpectedly — of meningitis - before he was able to give his written consent, a situation that those who drafted the legislation setting up the HFEA admit candidly that they had not foreseen. Some creative legal footwork, involving the case being characterized as exceptional, has been necessary to stay, at least technically, within this legislation. But, for the present, it seems human justice has prevailed. If the various legal systems in place across the world can apply the same measure of principled creativity to similar issues elsewhere, there is no reason why carefully crafted regulations should impede either scientific or human advancement.

\section{Heavenly prospects and glad tidings}

\section{President Clinton has accepted that science should not suffer from his efforts to balance the budget.}

$\Lambda$ fter two years of relentless gloom about their long-term funding prospects, scientists in the United States have cause this week for some mild celebration. There is good news in Japan, too, where a very different set of economic circumstances is leading to greater government investment in science.

President Bill Clinton's 1998 budget offers steady funding for most science agencies, and, in its projections for future years, lifts the threat that very deep cuts would have to take place in order to balance the US budget by 2002 (see page 565 ). The budget scarcely qualifies as a windfall for science; most agencies would obtain increased funding close to the rate of inflation. But, given the dark expectations of a year ago, it is being welcomed by a community that now holds high hopes that the Congress will ramp up the proposed increases.

The main reason for the improved science funding outlook is extraneous: Clinton has taken advantage of both improved economic projections and the political disarray of his opponents to present a budgetbalancing plan that includes few real cuts in non-defence government spending. In practice, his budget will increase the deficit by $\$ 5$ billion next year, at a time when rapid economic growth ought to allow it to fall. But science lobbyists also detect, with some justification, evidence that their message has finally been getting through in Washington. The president himself has certainly shown increased interest in science over the past six months. The change appears to date from his successful television appearances praising NASA's alleged discovery of life on a meteorite from Mars. In a series of interviews, and subsequently on the campaign trail last autumn, the president began to warm to scientific themes (see Nature 383, 566; 1996). By the time of his fourth State of the Union address last week - his first to mention science at all - he was ready to embark upon a lengthy eulogy, stressing space exploration, AIDS research and the Human Genome Project.

Not to be outdone, Republicans in the Senate have come up with their own bold initiatives to boost spending on science. Jack Gibbons, Clinton's science adviser, has observed that "the public and the vast majority of the Congress support a strong research program". As long as the public and the Congress are willing to join the president in turning a blind eye to the budget deficit, it appears that they will get one. 